\title{
Unexpected Faults: Managing Entomology Collections through the 2010/11 Canterbury Earthquakes
}

\author{
John W. M. Marris ${ }^{\ddagger}$, Cor J. Vink ${ }^{\S}$ \\ ‡ Entomology Research Collection, Bio-Protection Research Centre, Lincoln University, Christchurch, New Zealand \\ $\S$ Canterbury Museum, Christchurch, New Zealand
}

Corresponding author: John W. M. Marris (john.marris@lincoln.ac.nz)

Received: 07 Jun 2018| Published: 04 Jul 2018

Citation: Marris J, Vink C (2018) Unexpected Faults: Managing Entomology Collections through the 2010/11

Canterbury Earthquakes. Biodiversity Information Science and Standards 2: e27268.

https://doi.org/10.3897/biss.2.27268

\section{Abstract}

On 4 September 2010, a 7.1 magnitude earthquake struck near Darfield, 40 kilometres west of Christchurch, New Zealand. The quake caused significant damage to land and buildings nearby, with damage extending to Christchurch city. On 22 February 2011, a 6.3 magnitude earthquake struck Christchurch, causing extensive and significant damage across the city and with the loss of 185 lives. Years on from these events, occasional large aftershocks continue to shake the region.

Two main entomological collections were situated within close proximity to the $2010 / 11$ Canterbury earthquakes. The Lincoln University Entomology Research Collection, which is housed on the $5^{\text {th }}$ floor of a 7 storey building, was $27.5 \mathrm{~km}$ from the 2010 Darfield earthquake epicentre. The Canterbury Museum Entomology Collection, which is housed in the basement of a multi-storeyed heritage building, was $10 \mathrm{~km}$ from the 2011 Christchurch earthquake epicentre. We discuss the impacts of the earthquakes on these collections, the causes of the damage to the specimens and facilities, and subsequent efforts that were made to prevent further damage in the event of future seismic events. We also discuss the wider need for preparedness against the risks posed by natural disasters and other catastrophic events. 


\section{Keywords}

Earthquake, entomology, collection, damage, management

\section{Presenting author}

John W. M. Marris, Cor J. Vink 